\title{
0-157＼cjkstart軟骨伝導補聴器の臨床試験の結果
}

○西村忠已 ${ }^{11}$ 、細井裕司 ${ }^{2}$ 、山中敏彰1)、北原 糺

奈良県立医科大学 耳鼻咽喉・頭頸部外科 ${ }^{12}$ 、奈良県立医科大学 ${ }^{22}$

外耳道閉鎖症などの通常の補聴器では対応困難な難聴に対して軟骨伝導を用いた補聴器を開発し、2013年 2 月より臨床試 験を開始した。得られた結果などから2017年 1 月に医療機器として販売するための承認を得る申請を行い、7月に PMDA より承認を得た。11月13日に販売開始となり、臨床試験は終了となったが、その間47例が臨床試験に参加した。重度感音難 聴など適応外と思われる 3 例、通院の継続が困難など初期に離脱した 2 例を除く 42 例（襾耳装用23例、片耳装用 19 例）中 40 例が試験期間終了まで継続使用した。臨床試験開始前までの使用デバイスは、気導補聴器 5 例、骨導補聴器18例、気導と骨 導補聴器の併用 1 例、BAHA 2 例であり、途中で中止となった 2 例中 1 例は片側先天性外耳道閉鎖、対側正常な例で、 1 例 は両側先天性外耳道閉鎖症で骨導補聴器使用例であった。BAHA を使用していた 2 例についてはBAHA と併用していた。 試験期間中重篤な副作用は認めなかった。

\section{0-158 当科補聴器外来における補聴器適合の現況}

○原口美穂子、齋藤明彦、後藤 穣

日本医科大学多摩永山病院 耳鼻咽喉科

高齢化社会の進行に伴い難聴者は増加しており、生活の質を保つために補聴器は重要な役割を果たす。今回、過去 6 年間 の当科補聴器外来に扔ける補聴器適合の現況につき統計的検討を行ったので報告する。2011年 6 月〜2017年 1 月に当科補聴 器外来を受診した患者 169 名を対象とし、良聴耳聴力、最良語音明瞭度、補聴器購入率、装用耳、補聴器型、補聴器購入価 格について検討した。平均年齢は74.0歳（13〜96歳）であった。補聴器購入に至った患者は118名、新規で補聴器装用を検 討するも購入に至らなかった患者は 38 名、補聴器を既に持っており調整目的で受診した患者は 13 名であった。補聴器購入に 至った患者の平均聴力は $48.4 \mathrm{~dB}$ 、平均最良語音明瞭度は $77.0 \%$ あった。補聴器購入に至らなかった患者の平均聴力は 44. $0 \mathrm{~dB}$ 、平均最良語音明暸度は $82.4 \%$ であった。良聴耳の聴力、最良語音明瞭度ともに購入群と非購入群の間で有意差を 認めなかった。

\section{0-159＼cjkstart補聴器外来における工夫}

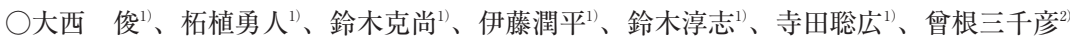

名古屋第一赤十字病院 耳鼻咽喉科 ${ }^{1)}$ 、名古屋大学 医学部 耳鼻咽喉科 ${ }^{2}$

補聴器は、装用の不快感から補聴器の購入を断念したり、購入後に使用をやめたりすることは少なくない。当院では補聴 器外来の体制を整えることで、この問題の改善を試みてきたので今回発表する。補聴器のフィッティングには、適切なカウ ンセリングと頻回の調整が必要である。そこで、医師が適応を判断し、言語聴覚士が補聴器にかかわるカウンセリングを行 う具体的な流れを作った。調整途中の補聴器特性やファンクショナルゲインの測定を行うことは調整の鍵であり、それを言 語聴覚士が実施しながら認定補聴器技能者と調整を進め、適合の判断は医師が行うという流れも確立しつつある。一方、調 整のための頻回の通院が病院診療では非現実的であり、当院では院内の福祉医療機器販売店の一画に「補聴器コーナー」を 設置することにより、認定補聴器技能者による $1 、 2$ 週間に 1 度の補聴器調整を実現した。

このように、補聴器フィッティングを円滑に行うためには、医師、言語聴覚士、認定補聴器技能者の良好な連携が必要不 可欠であると実感している。

\section{0-160 集音器と補聴器の特性および客観的、主観的評価に関する検討}

亀井昌代 ${ }^{1}$ 、佐藤宏昭 ${ }^{11}$ 、小田島葉子 ${ }^{2}$

岩手医科大学 耳鼻咽喉科・頭頸部外科 ${ }^{1)}$ 、小田島耳鼻咽喉科医院 ${ }^{2}$

補聴器は管理医療機器であるが、集音器はあくまで「家電製品」として販売されている。集音器（助聴器と称される機器 を含む）は、インターネットやテレビ、新聞、雑誌の広告などで目にすることが多く、価格も補聴器に比較してかなり安く 設定されている。耳鼻咽喉科の外来でも集音器の使用者に遭遇することがあり、補聴器外来でもよく聞き取れないなど、相 談されることもあるため、両者の特性と使用評価について比較検討した。今回われわれは、通信販売されている集音器につ いて周波数特性を純音掃引と ISTS（国際語音検查信号）にて測定した。また、無響室内でHATS（ダミーヘッド）に集音 器や補聴器を装着させ、ISO8253-3 に準じて雑音負荷を行い 57-S 語表と CI-2004 文検査を録音した。録音した音について、 聴力正常例を対象として雑音負荷語音明瞭度検査および、VAS と形容詞対を用いた SD 法による印象評価を施行した。集音 器、補聴器について語音明暸度による客観的評価と、印象評価による主観的評価について検討したので報告する。 


\section{0-161重複障害児者の補聴器装用について}

$\bigcirc$ 別府玲子 ${ }^{1)}$ 、栗田和洋 ${ }^{2}$

愛知県青い鳥医療療育センター 耳鼻咽喉科 ${ }^{1)}$ 、愛知県青い鳥医療療育センター 整形外科 ${ }^{2}$

愛知県青い鳥医療療育センターは重症心身障害児者、肢体不自由児、発達障害児者への医療と療育を提供する複合施設 で、当科では、障害児者の一般的な耳鼻咽㑨科疾患の診断、治療を行うとともに、聴覚障害児者の聴覚管理扮よび、補聴器 装用が必要な症例に対しては、補聴器装用指導、訓練を行っている。今回、平成21年 4 月〜平成29年11月までの間に補聴器 装用指導、訓練を行った重複障害児者12症例について診断から訓練に扔ける問題点を検討したので報告する。難聴の診断に ついては、対象者のほとんどが知的障害を合併しており、ABR、ASSR 等の他覚的聴力検査と乳幼児聴力検査を施行して総 合的に聴覚評価を行った。12症例の原疾患は先天性サイトメガロウイルス感染症、先天性筋線維症、先天性骨異形成症、肺 低形成症、コルネリア・デ・ランゲ症候群などさまざまであった。補聴器装用開始年齢は、身体の重症度に比例して遅くな る傾向が認められ、装用時間は、場面装用の症例も多く知的障害が軽度なほど長時間装用が可能であった。

\section{0-162 メニエール病におけるカロリックテストと vHIT の結果の乘離に関する検討}

○瀬尾 徹、小林孝光、白石 功、藤田 岳、北野睦三、齋藤和也、土井勝美

近畿大学 医学部 耳鼻咽喉科

Video Head Impulse Test(vHIT) は、簡便な前庭機能検查として注目されている。前庭神経炎や聴神経腫瘍では、その結 果はカロリックテストの結果とよく一致する。一方、メニエール病に扔いては両者の結果は乘離する。その原因を探る目的 で、メニエール病確実例のうちカロリックテストで半規管機能低下を認めた 29 例について、ロジスティック回帰分析を用 い、乘離に影響を及ぼす因子について検討した。その結果は、年齢、罹病期間、ステージ、めまい発作回数、聴力について

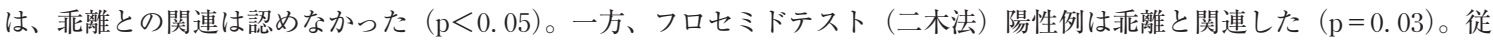
来、乘離の原因として感覚細胞の障害性の差あるいは内リンパ水腫による内リンパの流動性の問題との考えがあった。感覚 細胞の障害は年齢とともに増大するが、乘離は年齢とは関連しなかったので、前者は否定的である。フロセミドテストは半 規管の内リンパ水腫の存在を示すと考えられるので、むしろ後者が乘離の原因と推察された。

\section{0-163 前・後半規管の定量的 head impulse test (vHIT)}

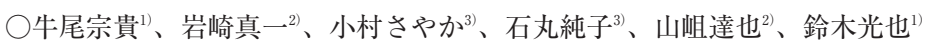

東邦大学医療センター佐倉病院 耳鼻咽喉科 ${ }^{11}$ 、東京大学 医学部 耳鼻咽喉科・頭頸部外科 ${ }^{2}$ 、

JCHO 東京山手メデイカルセンター 耳鼻咽䚐科 ${ }^{3)}$

【はじめに】vHITには水平半規管機能 $(\mathrm{h}-\mathrm{HIT})$ に加えて前・後半規管機能（a, p-HIT）も評価できる利点がある。a, $\mathrm{p}^{-}$ HIT の結果について報告する。【方法】前庭神経炎など一側前庭障害症例315例を対象として、温度刺激検查、cVEMP、3 平面の vHIT を施行した。vHITには EyeSeeCam ${ }^{\circledR}$ と ICS Impulse ${ }^{\circledR}$ を用いた (83症例には両機器)。【結果】上下前庭神経炎 などで温度刺激検査と cVEMPに高度障害がみられた場合には a, p-HITで異常がみられる割合が大きかったが、異常検出 率は外側半規管より低かった。上または下前庭神経炎における温度刺激検査、cVEMP、a， p-HIT の結果は、特に軽度障害

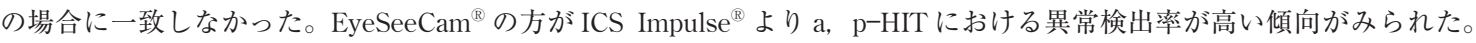
【結論】a，p-HIT は h-HIT と比較して従来の検査と結果に乘離がみられることが多かった。

\section{0-164 vHIT を用いた耳科手術後の半規管機能評価}

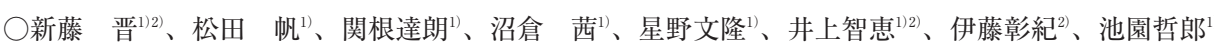
埼玉医科大学 耳鼻咽喉科 ${ }^{1)}$ 、埼玉医科大学 神経耳科 ${ }^{2)}$

耳科手術後の内耳障害は術者にとって常に気にかけなければいけない問題である。このうち螖牛機能については骨導の聴 力検査を行うことで術直後から評価が可能である。一方半規管機能検查のゴールドスタンダードである温度刺激検査は、耳 内をパッキングするために術後しばらくは行うことが困難となる。また例え行ったとしても術後は外・中耳の形態が変化す るため、温度刺激検查によって術前後での半規管機能の比較を行うことは必ずしも適切とはいえないケースがある。2009年 に開発された vHIT は温度刺激検査とは異なり、回転刺激によって半規管機能を評価する検査であり、耳科手術の翌日から 検査・評価が可能である。われわれはこのvHIT を用いて各種の耳疾患に対し耳科手術を行った患者を対象に、半規管機能 の評価を行ったので報告する。 